\title{
PEMANFAATAN TEPUNG UMBI MINOR SEBAGAI ALTERNATIF STABILIZER ALAMI UNTUK MENINGKATKAN MUTU FISIK DAN INDERAWI ES KRIM BUAH NAGA (Hylocereus polyrhizus sp.)
}

\section{[Utilization of Flour from Minor Tubes as an Alternative Natural Stabilizer in Increasing Physical and Sensory Quality from Dragon Fruit Ice Cream (Hylocereus polyrhizus sp.)]}

\section{Rucitra Widyasari*, Yeni Sulastri, Rini Nofrida, Mohammad Abbas Zaini, Arif Nasrullah, Zainuri}

*Program Studi Ilmu dan Teknologi Pangan, Fakultas Teknologi Pangan dan Agroindiustri, Universitas Mataram *email: rucitrawidyasari@unram.ac.id

Diterima 10 Januari 2018/ Disetujui 18 April 2018

\begin{abstract}
The study aimed to analyze the effect of using some local tuber flour as alternative stabilizer on dragon fruit ice cream through physical and sensory quality. Tuber local utilizing was lombos (porang), meanwhile uwi, talas belitung, and CMC as a control. The research was conducted in three stages: 1) making of flours: lombos, porang, and talas belitung 2) making dragon fruit ice cream in addition of natural stabilizer of lombos flour, porang flour and talas belitung flour under various concentration levels at 0.1, 0.3 and $0.5 \% \mathrm{w} / \mathrm{v}$ and 3) determining of the best treatment from each natural stabilizer. The result showed that was red dragon fruit ice cream with $0.5 \%$ porang flour as stabilizer had similar effect to CMC as an ice cream stabilizer. The porang 0,5\% treatment was overrun, 87,41\% emulsion stability, melting time 95,45 minutes / 100 gram, 54,5 dPa.s viscosity, and 3.95 hedonic score (mildly like to like), 4.33 (like) hedonic texture and 4,53 (mildly gentle to soft) texture with scoring test.
\end{abstract}

Keywords: ice cream, tuber, stabilizer

\section{ABSTRAK}

Penelitian ini bertujuan untuk menganalisa pengaruh dari penggunaan beberapa tepung umbi lokal sebagai alternatif stabilizer pada es krim buah naga terhadap sifat fisik dan sensori. Umbi lokal yang digunakan adalah umbi lombos (porang), umbi uwi dan umbi talas belitung serta CMC sebagai kontrol. Penelitian dilakukan dalam tiga tahap yaitu 1) pembuatan tepung talas belitung, pembuatan tepung umbi porang, pembuatan tepung umbi uwi, 2) pembuatan es krim buah naga dengan penambahan stabilizer alami berupa tepung umbi talas belitung, tepung umbi porang, tepung uwi pada berbagai tingkat konsentrasi yaitu $0.1,0.3$ dan $0.5 \% \mathrm{~b} / \mathrm{v}$ dan 3) penentuan perlakuan terbaik dari masing-masing penggunaan penstabil alami. Berdasarkan hasil penelitian diketahui bahwa es krim buah naga merah yaitu jenis penstabil porang dengan konsentrasi $0,5 \%$ dan mampu menyamai CMC sebagai penstabil es krim. Pada perlakuan porang $0,5 \%$ diperoleh overrun $68,50 \%$, stabilitas emulsi $87,41 \%$, waktu leleh 97.7 menit/100 gram, viskositas $54.5 \mathrm{dPa}$ s, skor hedonik rasa 3,95 (agak suka mengarah ke suka), hedonik tekstur 4,33 (suka), skoring tekstur 4,53 (agak lembut mengarah ke lembut).

Kata kunci: es krim, umbi, stabilizer

\section{PENDAHULUAN}

Salah satu komoditi yang cukup potensial untuk dikembangkan menjadi es krim adalah buah naga merah. Buah naga merah kaya akan nutrisi seperti vitamin A, C dan $\mathrm{E}$, protein, serat serta sumber mineral, seperti kalsium, fosfor dan magnesium (Cahyono, 2009).

Permasalahan yang sering timbul pada proses pembuatan es krim adalah viskositas rendah, overrun rendah, dan kecepatan meleleh yang relatif cepat. Perlu adanya usaha untuk mencapai kualitas es krim yang baik (Hakim, 2013). Hal ini dapat diatasi dengan penambahan stabilizer atau bahan penstabil. Bahan penstabil merupakan zat pembentuk gel (gelling agents) atau bahan pengental yang banyak dimanfaatkan dalam industri makanan untuk meningkatkan kualitas es krim. Penggunaan bahan penstabil memiliki fungsi, yaitu untuk mempertahankan stabilitas emulsi, mencegah pembentukan kristal es yang besar, memberikan keseragaman produk, menurunkan kecepatan meleleh, memperbaiki sifat produk, dan memperbaiki tekstur. Tekstur es krim juga dapat diperoleh dari proses pembekuan cepat yang akan menghasilkan tekstur es berukuran kecil, halus, dan lembut (Susrini, 2003). Bahan penstabil yang sering digunakan dalam pembuatan es krim antara lain agar-agar, 
CMC (Carboxy Methyl Cellulosa), gum arab, sodium alginat atau karaginan (Susilorini dan Sawitri, 2007). Namun, pada penelitian ini bahan penstabil yang digunakan bersumber dari umbi minor, yaitu umbi talas belitung, umbi lombos (porang) dan umbi uwi. Pemanfaatan tepung umbi minor dalam pembuatan es krim berfungsi sebagai stabilisator, meningkatkan kekentalan, pencegah kristalisasi, sebagai pengikat dan memperbaiki tekstur. Umbi minor adalah umbi-umbian lokal yang belum dimanfaatkan secara maksimal penggunaannya.

Pati dalam tepung umbi dapat bergelatinasi (Winarno, 1997), gelatinasi dari pati berperan dalam pembentukan es krim sehingga dapat menggantikan fungsi dari CMC (Carboxil Metil Celullose) sebagai bahan stabilisator kimiawi. Pati mempunyai kemampuan menyerap air sangat besar (Winarno, 2004) salah satu sifat dari pati sama seperti CMC yaitu dapat mengikat air, dimana kemampuan menyerap air sangat besar (Winarno, 2004). Menurut Maape dan Donald (1979), Yamaguchi (1983) dan Pinus et al. (1986) bahwa salah satu komponen karbohidrat dalam talas-talasan adalah polisakarida yang berbentuk gum, yaitu glukomanan. Glukomanan merupakan suatu bahan pengemulsi (emulgator) pada industri makanan, kertas dan kosmetika, karena bahan ini di dalam cairan akan membentuk gel yang mempunyai viskositas cukup tinggi (Meir, 1967; Ohtsuki, 1968; Tipson, 1975).

Berdasarkan uraian tersebut, maka dilakukan penelitian untuk mengetahui penambahan tepung dari berbagai umbi lokal dengan konsentrasi yang tepat agar dapat menghasilkan es krim buah naga berkualitas baik, ditinjau dari kualitas fisik dan organoleptik es krim.

\section{METODOLOGI}

\section{Bahan dan Alat}

Bahan utama yang digunakan dalam proses pembuatan es krim buah naga merah antara lain buah naga merah, talas belitung, umbi iles-iles (lombos/porang) dan umbi uwi, susu krim bubuk, susu skim, gula pasir, pengemulsi, garam, CMC dan es batu. Bahan yang digunakan untuk analisis adalah aquades.

Alat-alat yang digunakan dalam penelitian ini adalah timbangan analitik, pisau, blender, pengaduk, baskom, homogenizer, ice cream maker, refrigator, freezer. Alat yang digunakan untuk analisis adalah botol timbang, oven, desikator, gelas ukur, refraktometer dan kain penyaring.

\section{Tahapan Penelitian}

Penelitian dilakukan dalam tiga tahap yaitu 1) pembuatan tepung talas belitung, pembuatan tepung umbi iles-iles, pembuatan tepung umbi uwi, 2) pembuatan es krim buah naga dengan penambahan stabilizer alami berupa tepung umbi talas belitung, tepung umbi iles-iles, tepung uwi dan 3) penentuan perlakuan terbaik dari masing-masing penggunaan penstabil alami.

\section{Pembuatan Tepung Talas Belitung, Pembuatan Tepung Umbi Iles-Iles, Pembuatan Tepung Umbi Uwi \\ Umbi yang akan diproses setalah} melalui proses pengupasan kemudian dilakukan pencucian dan perendaman dengan natrium metabisulfit $0.5 \%$ selama 30 menit. Selanjutnya dilakukan pengecilan ukuran hingga $2 \mathrm{~mm}$. Proses berikutnya adalah pengovenan atau pengeringan selama 8 jam dengan suhu $50^{\circ} \mathrm{C}$, lalu kemudian dilakukan proses penepungan dan pengayakan dengan saringan 100 mesh. Umbi iles-iles memiliki kadar oksalat yang cukup tinggi sehingga perlu dilakukan penurunan kadar oksalat dengan perendaman dalam larutan garam 5\% selama 4 jam dan pencucian dengan air mengalir.

\section{Pembuatan Es Krim Buah Naga Dengan Penambahan Stabilizer Alami Berupa Tepung Umbi Talas Belitung, Tepung Umbi Iles-Iles, Tepung Uwi}

Pembuatan es krim menggunakan bahan baku ekstrak buah naga merah, susu krim, susu skim, kuning telur, gula, air, whip cream dan ditambahkan berbagai jenis tepung umbi dengan konsentrasi yang berbeda. Setalah diaduk hingga rata selama 1 jam, kemudian di aging selama 4 jam pada suhu $5^{\circ} \mathrm{C}$ dan dilanjutkan dengan pembekuan pada suhu $-30^{\circ} \mathrm{C}$.

\section{Penentuan perlakuan terbaik dari masing-masing penstabil alami. penggunaan} Penentuan

perlakuan terbaik dilakukan dengan melihat pengaruh penambahan penstabil alami pada berbagai konsentrasi terhadap beberapa parameter fisik dan organoleptik es krim. 


\section{Parameter Penelitian}

Parameter yang diamati dalam penelitian meliputi sifat fisik dan organoleptik. Parameter sifat fisik utama yang diamati adalah overrun, stabilitas emulsi, daya leleh es krim buah naga yang dilakukan dengan metode dari modifikasi Malaka (2010), viskositas dan warna. Sedangkan parameter organoleptik meliputi rasa, warna, tekstur dan aroma dilakukan menggunakan uji Hedonic dan uji Scoring (Rahayu,1998).

\section{Rancangan Percobaan dan Analisis Data}

Rancangan penelitian dilakukan dengan Rancangan Acak Lengkap Faktorial dengan perlakuan penambahan berbagai jenis stabilizer pada berbagai konsentrasi. Konsentrasi stabilizer yang digunakan 0,1 ; 0,3 ; dan $0,5 \%$ (b/b) dari total formulasi bahan. Selain itu, juga dilakukan pembuatan es krim menggunakan stabilizer komersial yaitu CMC sebagai stabilizer pembanding/control pada konsentrasi yang sama.

Semua perlakuan diulang sebanyak 3 kali sehingga didapatkan 36 unit percobaan. Data yang terkumpul dianalisa menggunakan analisa keragaman dengan taraf $5 \%$. Jika terjadi perbedaan nyata antar perlakuan diuji lanjut dengan menggunakan Beda Nyata Terkecil (BNT) pada taraf 5\%.

\section{HASIL DAN PEMBAHASAN}

\section{Sifat Fisik Es Krim Buah Naga Merah Pada Berbagai Jenis Dan Konsentrasi Penstabil}

\section{Overrun}

Persentase overrun pada es krim buah naga merah yang diberi perlakuan jenis dan konsentrasi penstabil menujukkan kisaran rataan $31,73 \%$ sampai $80,91 \%$. Overrun rata-rata tertinggi $(80,91 \%)$ dihasilkan pada es krim buah naga merah yang menggunakan bahan penstabil uwi ungu 0,3\% sedangkan overrun rata-rata terendah (31,73\%) dihasilkan pada es krim buah naga merah dengan penstabil talas belitung $0,5 \%$ (Gambar 1).

Berdasarkan hasil analisis sidik ragam, perlakuan jenis penstabil, konsentrasi bahan penstabil dan interaksi kedua perlakuan tersebut berpengaruh nyata terhadap overrun es krim buah naga merah yang dihasilkan. Hasil uji lanjut Duncan, diperoleh bahwa overrun es krim dengan penstabil uwi ungu berbeda nyata dengan penstabil CMC dan talas Belitung namun tidak berbeda nyata dengan porang. Hasil uji lanjut Duncan yaitu overrun es krim buah naga merah dengan penambahan penstabil $0,1 \%$ dan $0,3 \%$ berbeda nyata dengan penambahan penstabil $0,5 \%$ den dengan meningkatnya konsentrasi bahan penstabil maka overrun semakin menurun.

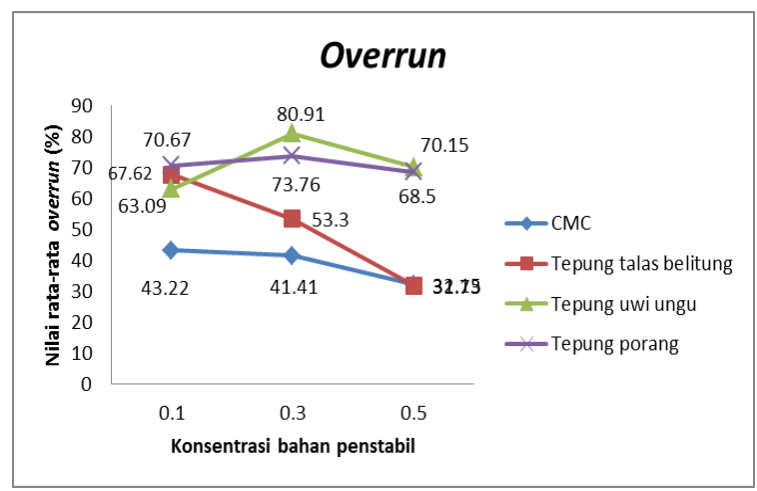

Gambar 1. Pengaruh jenis dan konsentrasi penstabil terhadap overrun es krim buah naga merah

Menurut Arbuckle (1981), jika kekentalan adonan meningkat maka daya pengembangan (overrun) akan semakin menurun. Air yang terikat didalam struktur molekul menyebabkan adonan makin kental. Semkin kental adonan, tegangan permukaan menjadi lebih tinggi akibatnya udara sukar menembus permukaan adonan dan produk lebih sukar mengembang. Bila konsentrasi penstabil dalam adonan kurang, maka tidak cukup bahan penstabil untuk mengikat air bebas yang ada, akibatnya air tersebut akan menghambat udara untuk masuk dan menghalangi pengembanagn produk. Tekstur es krim yang disukai adalah tekstur yang lembut. Menurut Arbuckle (1981), tekstur yang lembut dapat diperoleh jika kristal es yang terbentuk cukup kecil (35 4) dan cukup banyak udara yang terperangkap dalam adonan selama pembekuan sehingga overrun produk es krim tersebut cukup tinggi.

\section{Stabilitas Emulsi}

Stabilitas emulsi es krim menunjukkan daya tahan adonan es krim terhadap pemisahan protein susu dan lemak susu. Emulsi yang tidak stabil menyebabkan protein akan menggumpal dan mengendap di dalamnya sehingga terjadi pemisahan protein dengan lemak (Arbuckle, 1986). Stabilitas emulsi biasanya ditunjukkan oleh dua keadaan, yaitu proses pembentukan krim dan pemisahan fase. Salah satu cara untuk mempertahankan kestabilan emulsi es krim 
adalah dengan meningkatkan kekentalannya melalui penambahan penstabil ke dalam adonan es krim.

Nilai stabilitas emulsi pada es krim buah naga merah yang diberi perlakuan berbagai jenis dan konsentrasi penstabil menujukkan kisaran rataan $81,21 \%$ hingga $93.45 \%$. Nilai stabilitas emulsi rata-rata tertinggi dihasilkan oleh es krim buah naga merah yang menggunakan bahan penstabil Tepung Porang $0.1 \%$ yaitu sebesar $93.45 \%$, sedangkan nilai stabilitas emulsi rata-rata terendah $(81,21 \%)$ dihasilkan oleh es krim buah naga merah dengan bahan penstabil talas belitung $0,1 \%$. Nilai rata-rata stabilitas emulsi es krim buah naga merah pada berbagai jenis dan konsentrasi penstabil dapat dilihat pada Gambar 2.

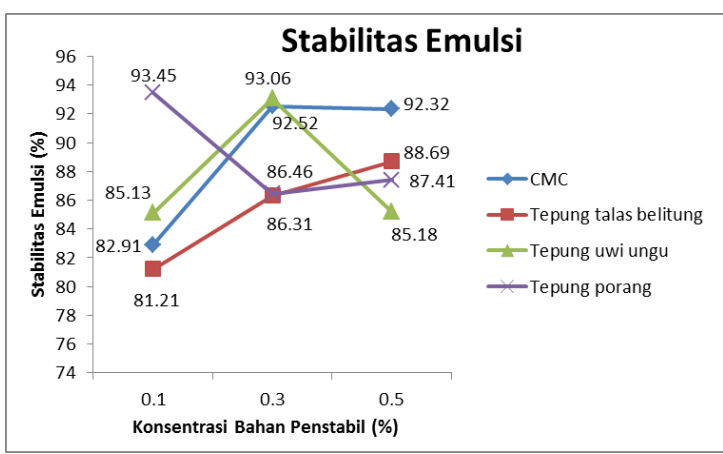

Gambar 2. Pengaruh jenis dan konsentrasi penstabil terhadap stabilitas emulsi es krim buah naga merah

Berdasarkan hasil analisis sidik ragam bahwa perlakuan jenis penstabil, konsentrasi bahan penstabil dan interaksi kedua perlakuan tersebut berpengaruh nyata terhadap stabilitas emulsi es krim buah naga merah yang dihasilkan. Uji lanjut Duncan menunjukkan bahwa penggunaan penstabil CMC tidak berbeda nyata dengan penstabil tepung porang namun kedua jenis penstabil tersebut berbeda nyata dengan penstabil tepung talas belitung dan tepung uwi ungu. CMC (penstabil kontrol) merupakan penstabil es krim yang telah digunakan secara komersial karena mampu menghasilkan es krim dengan tekstur yang lembut dan stabilitas yang tinggi.

Hasil penelitian menunjukkan bahwa porang mampu menyamai kemampuan CMC dalam mempertahankan stabilitas emulsi es krim buah naga merah. Hal ini disebabkan oleh adanya glukomanan pada porang sehingga mampu menstabilkan es krim buah naga merah. Suatu emulsi bersifat stabil apabila tidak terjadi pemisahan antar fasefase, tiga komponen utama pembentukan emulsi yaitu fase terdispersi (lemak), fase pendispersi (air) dan emulsifier.

Semakin tinggi penstabil maka stabilitas emulsi cenderung semakin meningkat. Konsentrasi penstabil yang semakin tinggi di dalam adonan es krim akan mengikat lebih banyak partikel-partikel es dan dibantu dengan proses homogenisasi adonan yang sempurna menyebabkan adonan menjadi lebih kental dan memiliki kestabilan yang tinggi. Arbuckle (1986) menyatakan bahwa stabilitas emulsi dipengaruhi oleh jenis dan jumlah bahan penstabil, ukuran dan keseragaman globula lemak, serta kekentalan adonan. Semakin kecil dan semakin seragam globula lemak maka stabilitas emulsi semakin tinggi. Oleh karena itu, perpaduan jenis dan proses homogenisasi adonan yang sempurna akan menyebabkan adonan menjadi kental dan memiliki ukuran globula lemak yang kecil sehingga stabilitas emulsi yang dihasilkan tinggi.

\section{Waktu Leleh}

Waktu leleh / daya leleh adalah salah satu faktor mutu yang sangat menentukan mutu es krim, karena waktu leleh akan memberikan gambaran berapa lama es krim dapat mempertahankan teksturnya setelah es krim dikeluarkan dari freezer. Es krim yang terbaik adalah es krim yang paling tahan terhadap pelelehan pada saat dihidangkan pada suhu ruang, sehingga semakin lama/besar waktu leleh es krim maka es krim tersebut semakin baik kualitasnya. Waktu leleh es krim sangat dipengaruhi oleh bahanbahan yang digunakan dalam pembuatan es krim. Salah satu bahan yang sangat berpengaruh terhadap waktu leleh adalah jenis dan konsentrasi bahan penstabil. Bahan penstabil dapat mencegah pelelehan yang berlebih, bertanggung jawab terhadap bentuk body, kelembutan dan kesegaran. (Goff, 2000). Pengaruh jenis dan konsentrasi penstabil yang digunakan terhadap waktu leleh es krim buah naga merah dapat dilihat pada Gambar 3.

Es krim yang baik mempunyai kecepatan meleleh antara $20-30$ menit/100 gram (1200-1800 detik/100 gram bahan) pada suhu kamar (Akesowan, 2008). Pada penelitian ini semua perlakuan memenuhi kriteria tersebut. Gambar 3 menunjukkan rata-rata waktu leleh es krim buah naga merah 57.6 hingga 97.7 menit/100 gram. Kecepatan leleh es krim sari buah naga merah cenderung meningkat dengan semakin banyaknya konsentrasi penstabil yang 
Versi Online:

http://www.profood.unram.ac.id/index.php/profood e-ISSN: 2443-3446

ditambahkan. Hal ini disebabkan apabila penstabil didispersikan pada fase cair, maka penstabil akan mengikat sejumlah besar air dan membentuk kerangka gel yang dapat mencegah molekul air bergerak bebas dan membentuk selaput yang terbentuk akan melindungi komponen es krim dari pengaruh suhu luar dan membatasi mobilitas air pada emulsi. Oleh karena itu semakin banyak konsentrasi penstabil yang ditambahkan maka akan mengakibatkan terjadi peningkatan jumlah air bebas yang terperangkap sehingga akan menghasilkan es krim yang lebih tahan dan memiliki waktu leleh paling lama (Hartel, 2004).

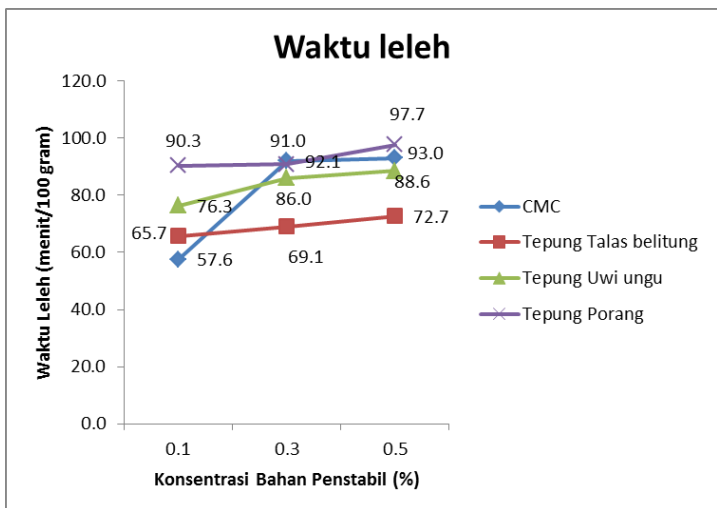

Gambar 3. Pengaruh jenis dan konsentrasi penstabil terhadap waktu leleh es krim buah naga merah

Waktu leleh porang bahkan lebih besar/lama dibandingkan dengan waktu leleh CMC yang pada penelitian ini berperan sebagai kontrol karena CMC adalah penstabil komersial yang selama ini digunakan oleh kebanyakan industri es krim, karena CMC memiliki kemampuan mengikat air, molekul molekul air terperangkap dalam tekstur gel sehingga es krim tidak cepat meleleh (Winarno, 1997). Porang memiliki mempunyai kemampuan yang cukup kuat dalam mengikat air bebas dalam produk membentuk kerangka gel yang kuat sehingga transfer panas produk menjadi lebih rendah dan lebih tahan terhadap pelelehan. Hal ini disebabkan karena kandungan bahan yang terdapat pada porang, menurut Maape dan Donald (1979), Yamaguchi (1983) dan Pinus et al. (1986) bahwa salah satu komponen karbohidrat dalam talas-talasan adalah polisakarida yang berbentuk gum, yaitu glukomanan.

Porang menghasilkan waktu leleh paling lama karena memilki kandungan glukomanan paling tinggi diantara umbiumbian lain yaitu sekitar $55 \%$ dari bahan kering (Ohtsuki 1968; Jansen et al. 1996;
Pro Food (Jurnal IImu dan Teknologi Pangan)

Vol 4 No. 1 Mei 2018

ISSN: 2443-1095

Sumarwoto 2005). Peran Glukomanan ini lah yang menyamai peran CMC dan pati pada produk emulsi seperti es krim. Hal ini sesuai dengan pernyataan Winarno (1997) yaitu pati mempunyai kemampuan menyerap air sangat besar, pati dapat bergelatinasi, gelatinasi dari pati berperan dalam pembentukan es krim, dapat menggantikan fungsi dari CMC (Carboxil Metil Celullose) sebagai bahan stabilisator kimiawi.

\section{Viskositas}

Viskositas adalah ukuran ketahanan zat cair untuk mengalir. Semakin meningkatnya viskositas menyebabkan hasil es krim buah naga merah mengental. Viskositas es krim mempengaruhi mobilitas molekul air dalam ruang antar partikel di es krim menjadi semakin sempit atau lebar. Pengaruh jenis dan konsentrasi penstabil yang digunakan terhadap viskositas es krim buah naga merah dapat dilihat pada Gambar 4.

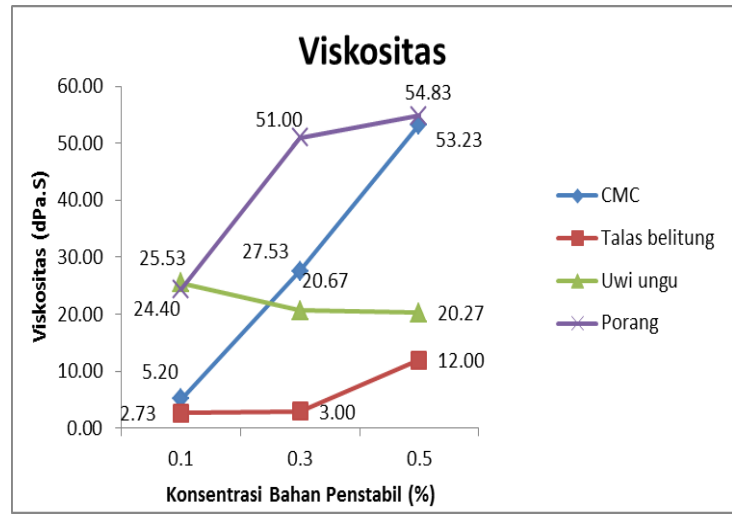

Gambar 4.Pengaruh jenis dan konsentrasi penstabil terhadap viskositas es krim buah naga merah

Gambar 4 menunjukkan rata-rata viskositas es krim buah naga merah adalah 2.73 dPa.s hingga 54.83 dPa.s. Viskositas es krim sari buah naga merah cenderung meningkat dengan semakin banyaknya konsentrasi penstabil yang ditambahkan. Hal ini disebabkan karena semakin banyak jumlah penstabil yang ditambahkan, semakin besar jumlah air yang dapat diikat dan membentuk kerangka gel yang dapat mencegah molekul air bergerak bebas sehingga akan menyebabkan viskositas meningkat. Menurut Estiasih (2005), viskositas dipengaruhi oleh konsentrasi dan berat moleku penstabil. Semakin tinggi nilai berat molekul dan konsentrasi penstabil maka viskositas produk akan semakin meningkat.

Berdasarkan Gambar 4, rata-rata viskositas tertinggi diperoleh pada perlakuan 
penambahan penstabil dengan konsentrasi $0,5 \%$ yaitu sebesar $54.83 \mathrm{dPa}$.S dengan jenis penstabil porang. Rata-rata viskositas terendah diperoleh pada perlakuan penambahan penstabil konsentrasi $0,1 \%$ yaitu sebesar $2.73 \mathrm{dPa}$.S dengan jenis penstabil talas belitung. Hal ini disebabkan karena porang mempunyai kemampuan yang cukup kuat dalam mengikat air bebas dalam produk membentuk kerangkan gel yang kuat. Kekentalan meningkat karena molekul air banyak terperangkap dalam struktur 3 dimensi akibat ikatan silang yang dibentuk susunan heliks dan interaksinya. Air yang sebelumnya berada di luar granula dan bebas bergerak dengan adanya penstabil maka tidak dapat bergerak bebas karena terserap dan terikat pada butiran penstabil sehingga keadaan larutan menjadi lebih mantap akibat peningkatan viskositas.

Menurut Maape dan Donald (1979), Yamaguchi (1983) dan Pinus et al. (1986) bahwa salah satu komponen karbohidrat dalam talas-talasan adalah polisakarida yang berbentuk gum, yaitu glukomanan. Glukomanan merupakan suatu bahan pengemulsi (emulgator) pada industri makanan, kertas dan kosmetika, karena bahan ini di dalam cairan akan membentuk gel yang mempunyai viskositas cukup tinggi (Meir, 1967; Ohtsuki, 1968; Tipson, 1975). Umbi iles-iles (porang) mengandung glukomanan yang tinggi, sekitar $55 \%$ dari bahan kering (Ohtsuki 1968; Jansen et al. 1996; Sumarwoto 2005). Kekentalan pada adonan es krim akan berpengaruh pada tingkat kehalusan tekstur, serta ketahanan es krim sebelum mencair.

\section{Warna}

Warna adalah spektrum cahaya yang dipantulkan oleh benda yang kemudian ditangkap oleh indra penglihatan manusia (yaitu mata) lalu diterjemahkan oleh otak sebagai sebuah warna tertentu. Warna yang diterima jika mata memandang objek yang disinari berkaitan dengan tiga faktor: sumber sinar, ciri kimia dan fisika objek, dan sifat-sifat kepekaan spektrum mata. Pada produk pangan warna merupakan faktor yang menentukan mutu, indikator kematangan, indikator kesegaran dan juga indikator kerusakan pangan.

Warna bahan diukur dalam unit $L, a$, b yang merupakan standar internasional pengukuran warna, diadopsi oleh CIE (Commission Internationale d'Eclairage). Pengukuran yang dilakukan adalah dengan menerjemahkan nilai unit $L, a, b$ kedalam nilai ohue. Dari hasil uji yang dilakukan, secara umum hasil analisa warna pada es krim buah naga berada pada nilai ohue $342^{\circ}-18$ yaitu berada daerah kisaran warna merah hingga ungu. Nilai ini sesuai dengan warna tampak pada es krim berdasarkan uji organoleptik. Warna merah hingga ungu ini dipengaruhi oleh pigmen warna dari buah naga merah yang berwarna merah keunguan. Pengaruh penambahan jenis dan konsentrasi bahan penstabil terhadap warna es krim buah naga merah Gambar 5.

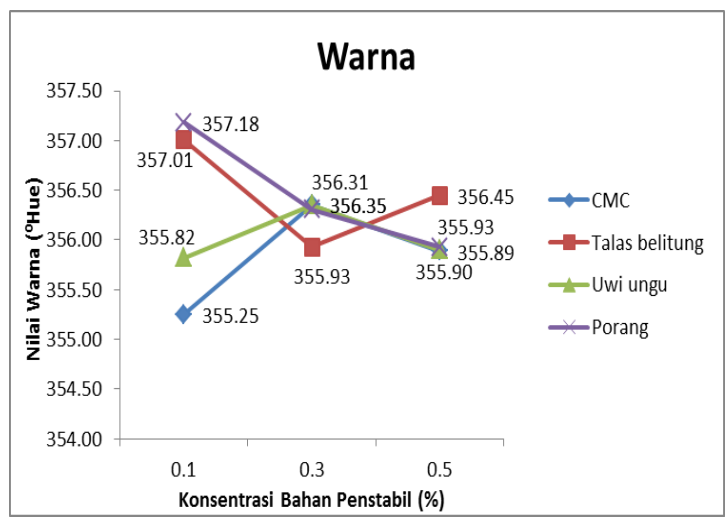

Gambar 5. Pengaruh jenis dan konsentrasi penstabil terhadap warna es krim buah naga merah

Gambar 5 menunjukkan rata-rata nilai oHue es krim buah naga merah adalah 355.25 hingga 357.18. Nilai tersebut berada pada daerah kisaran warna merah hingga ungu. Warna es krim sari buah naga merah cenderung menurun dengan semakin banyaknya konsentrasi penstabil yang ditambahkan, namun penurunan konsentrasi ini tidak terlalu besar, sehingga ketika dilakukan uji anova dilihat jenis penstabil dan konsetrasi yang ditambahkan berpengaruh terhadap nilai oHue, namun setalah dilakukan uji lanjut didapatkan hasil yang tidak signifikan. Hal ini disebabkan karena secara matematis nilai ${ }^{\circ}$ Hue mempunyai perbedaan nilai, namun secara daerah kisaran warna, nilai ${ }^{\circ}$ Hue tiap perlakuan masih berada pada kisaran yang sama yaitu merah hingga ungu. Perbedaan warna yang tidak signifikan tersebut dipengaruhi oleh penambahan penstabil yang sangat sedikit pada bahan yaitu maksimal hanya dalam jumlah 0,5\% sehingga tidak berpengaruh, dan juga karena warna dari penstabil putih kecoklatan dalam bentuk bubuk namun saat dilarutkan akan berwarna bening sehingga tidak mempengaruhi warna es krim secara 
Versi Online:

http://www.profood.unram.ac.id/index.php/profood e-ISSN: 2443-3446

keseluruhan. Sedangkan nilai a dan b porang dengan konsentrasi $0.5 \%$ menunjukkan nilai a 25.55 (merah), nilai b -6.16 (kuning mengarah ke biru-ungu) dan nilai L 73.37 (sangat cerah).

\section{Uji Organoleptik Es Krim Buah Naga 1. Uji Hedonik}

Uji hedonik merupakan pengujian yang paling banyak digunakan untuk mengukur tingkat kesukaan terhadap suatu produk. Tingkat kesukaan ini disebut skala hedonic, pada penelitian ini digunakan beberapaka skala yaitu : sangat suka, suka, agak suka, agak tidak suka, tidak suka, sangat tidak suka. Tingkat kesukaan ini kemudian dirubah menjadi skala numerik dan dilakukan analisis secara statistik. Penilaian dalam uji hedonik ini bersifat spontan. Ini berarti panelis diminta untuk menilai suatu produk secara langsung saat itu juga pada saat mencoba tanpa membandingkannya dengan produk sebelum atau sesudahnya.

Penelitian ini menggunakan komposisi yang sama untuk bahan baku utamanya, perbedaannya hanya pada bahan penstabil yang digunakan, karenanya uji hedonik yang dilakukan hanya untuk parameter rasa dan tekstur. Sedangkan parameter aroma dan warna tidak dilakukan karena tidak menunjukkan perbedaan bila dilihat secara sensori sederhana.

\section{Uji Hedonik Rasa}

Uji hedonik rasa pada konsentrasi 0.1 untuk semua bahan penstabil tidak menunjukkan perbedaan nyata pada taraf $5 \%$ sehingga tidak lakukan uji lanjut (Gambar 6). Menurut rata-rata hasil uji penstabil pada taraf $0.1 \%$, Talas Bitung (TB) memiliki ratarata yang sama dengan Uwi Ungu (UU) yaitu 3.47 (Agak suka mengarah ke tidak suka) dan Porang $(P)$ memiliki rata-rata tertinggi dengan 3.84 (Suka).

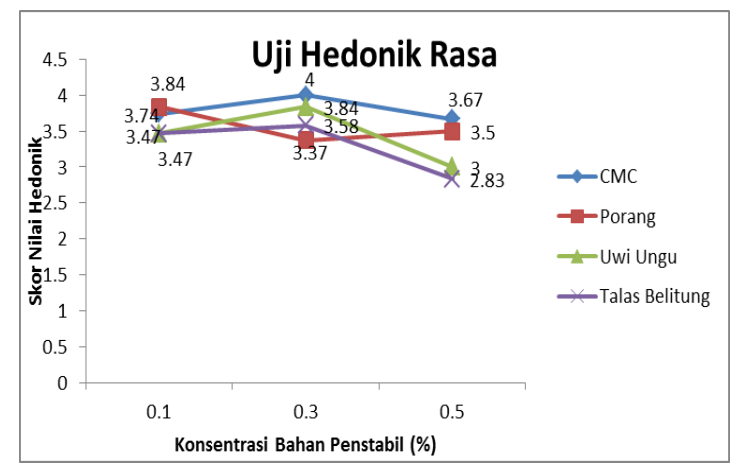

Gambar 6. Hasil Uji Hedonik Rasa Es Krim Buah Naga
Pro Food (Jurnal Ilmu dan Teknologi Pangan)

Vol 4 No. 1 Mei 2018

ISSN: 2443-1095

Demikian pula untuk uji hedonik rasa pada konsentrasi 0.3 untuk semua bahan penstabil, tidak terdapat perbedaan nyata baik untuk Talas Belitung, Porang, Uwi Ungu maupun CMC. Berdasarkan Gambar 6 dapat dilihat bahwa rata-rata CMC mendapatkan nilai tertinggi dengan skala 4 (Suka) sedangkan Porang mendapatkan nilai ratarata terendah dengan 3.37 (Agak suka mengarah ke tidak suka).

Seperti halnya pada konsentrasi 0.1 dan 0.3 pada konsentrasi 0.5 juga tidak terdapat perbedaan nyata terhadap rasa dari keempat bahan penstabil yang digunakan . Padahal CMC yang digunakan bertujuan sebagai kontrol pada es krim buah naga yang diproduksi. Sehingga dapat disimpulkan bahwa penggunaan bahan penstabil tidak mempengaruhi rasa secara organoleptik. Berdasarkan hasil uji (Gambar 6), rata-rata CMC menunjukkan skala hedonic tertinggi dengan nilai 4 (Suka) sedangkan UU mendapatkan rata-rata 3.53 (Agak suka mengarah ke suka).

\section{Uji Hedonik Tesktur}

Uji hedonik tekstur pada konsentrasi 0.1 menujukkan terdapat perbedaan nyata dari bahan penstabil yang digunakan, sehingga dilakukan uji lanjut dengan menggunakan uji duncan (Gambar 7). Dari hasil yang didapat TB berbeda nyata dengan CMC, $\mathrm{P}$ dan UU. Sedangkan CMC, P dan UU tidak menunjukkan perbedaan nyata dari ketiganya. Dan berdasarkan data rata-rata nilai hedonik (Gambar 7) CMC adalah yang paling disukai dengan nilai 3.67 (Agak suka mengarah ke suka) sedangkan TB adalah yang paling tidak disukai dengan nilai 2.83 (Tidak suka mengarah ke agak suka). Berdasarkan data dapat dilihat bahwa dengan konsentrasi minimal (konsentrasi standar untuk bahan penstabil pada es krim adalah dibawah $1 \%$, umumnya hanya $0.1-0.5 \%$ bahan penstabil mempengaruhi nilai hedonik terutama tekstur dari es krim buah naga yang dihasilkan namun dirasa kurang maksimal untuk mendapat nilai hedonik 4 (suka).

Namun konsentrasi 0.3 tidak menunjukkan hal yang sama, keempat bahan penstabil tidak menunjukkan hal yang berbeda nyata. Hal ini dimungkinkan bahwa dengan semakin banyak penstabil yang ditambahkan pada formulasi es krim buah naga maka tidak berpengaruh terhadap tekstur yang dihasilkan. Tapi jika dilihat dari rata-rata yang dihasilkan, nilai hedonik CMC 
Versi Online:

http://www.profood.unram.ac.id/index.php/profood e-ISSN: 2443-3446

adalah 3.83 (Agak suka mengarah ke suka) dan nilai hedonic TB 2.89 (Tidak suka mengarah ke agak suka) (Gambar 7) maka sama halnya dengan konsentrasi 0.1 dirasa konsentrasi penstabil yang ditambahkan kurang memuaskan untuk mencapai nilai minimal 4 (suka).

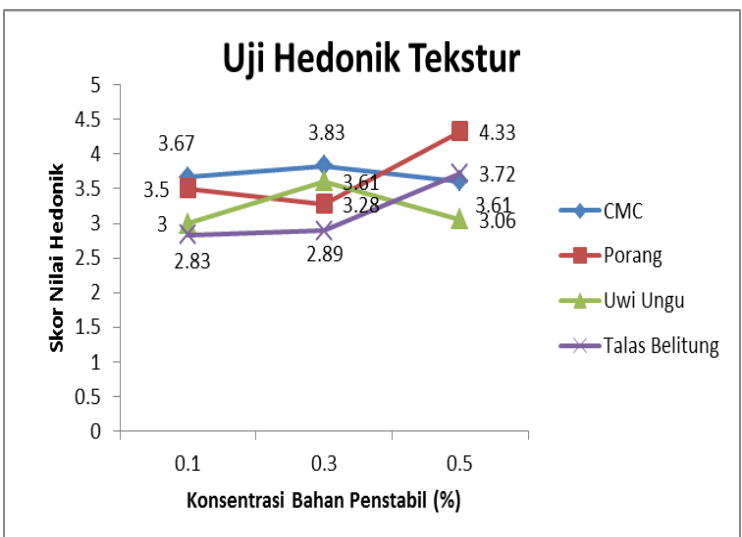

Gambar 7. Hasil Uji Hedonik Tekstur Es Krim Buah Naga

Hal ini dapat dilihat dari hasil dengan konsentrasi bahan penstabil 0.5 , berdasarkan hasil uji terdapat perbedaan nyata antara penstabil UU, P dan CMC, sedangkan TB tidak berbeda nyata dengan UU. Nilai rata-rata tertinggi adalah $\mathrm{P}$ dengan nilai 4.33 ( Suka) dan UU dengan nilai rata-rata terendah dengan nilai 3.06 (agak suka ke arah tidak suka).

Porang mengandung glukomanan dan memiliki kadar serat yang cukup tinggi dan dapat berfungsi sebagai thickening dan gelling agent yang mampu membentuk dan menstabilkan struktur gel sehingga dapat digunakan sebagai pengenyal makanan dan pengganti lemak dalam produk pangan. Glukomanan juga dapat digunakan sebagai bahan tambahan makanan (BTM) seperti pada mie atau pasta dikarenakan kemampuan glukomanan yang sangat besar dalam mengikat air karena kemampuannya itu porang sangat tepat diaplikasikan sebagai stabilizer karena diduga dapat meningkatkan viskositas fase pendispersi yang berguna dalam menstabilkan sistem emulsi es krim buah naga. Karenanya pada konsentrasi 0.5 porang memiliki tingkat kesukaan panelis lebih tinggi dibandingkan dengan CMC sebagai kontrol walaupun tidak berbeda nyata, sehingga dapat disimpulkan bahwa porang dapat digunakan sebagai alternative pengganti CMC sebagai penstabil komersil.

\section{Uji Skoring Tekstur}

Pengujian skoring dilakukan untuk mengetahui skor dari suatu mutu produk pangan, dalam hal ini adalah tekstur dari es krim buah naga. Skala yang digunakan untuk uji skoring ini adalah 1(Kasar), 2 (agak kasar), 3 (Netral), 4 (Agak Lembut) dan 5 (Lembut). Kekentalan es krim buah naga diharapkan juga mempengaruhi tekstur yang dihasilkan.

Konsentrasi $0.1 \%$ bahan penstabil yang ditambahkan sudah menunjukkan perbedaan yang nyata dari tekstur es krim yang dihasilkan, dimana CMC berbeda nyata dengan TB, UU dan P sekaligus memiliki ratarata tertinggi dengan nilai 3.68 (Netral kearah agak Lembut). Sedangkan TB, P dan UU tidak berbeda nyata, dengan nilai rata-rata terendah adalah TB dengan nilai 2.16 (Agak Kasar mengarah ke Kasar) (Gambar 8).

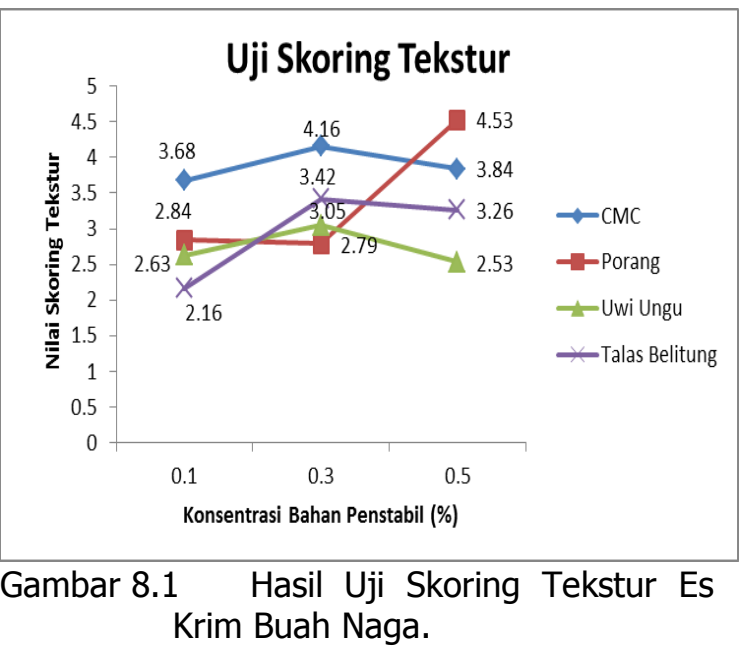

Hal tersebut juga terjadi pada konsentrasi $0.3 \%$ dimana bahan penstabil menunjukkan perbedaan yang nyata pada taraf $5 \%$, tekstur CMC berbeda nyata dengan $P$ dan UU namun tidak berbeda nyata dengan TB, sedangkan TB tidak berbeda nyata dengan UU dan P. Sama seperti konsentrasi $0.1 \%$, CMC menunjukkan rata-rata tertinggi dengan skor 4.16 ( Agak Lembut kearah lembut) dan $\mathrm{P}$ menunjukkan rata-rata 2.79 (Agak kasar kearah netral) (Gambar 8)

Pada konsentrasi $0.5 \%$, bahan penstabil $P$ berbeda nyata dengan CMC, TB dan UU sekaligus mendapatkan nilai rata-rata tertinggi dengan skor 4.53 (Agak lembut mengarah ke lembut). Hal ini juga membuktikan bahwa kandungan glukomanan yang lebih tinggi dapat mempertahankan viskositas dari es krim yang dihasilkan dan bahkan mendapatkan skor yang lebih baik 
daripada CMC sebagai kontrol. CMC yang digunakan pada konsentrasi ini hanya tidak berbeda nyata dengan TB, sedangkan UU merupakan bahan penstabil yang memiliki tekstur paling tidak disukai dengan skor 2. 53 ( Agak kasar mengarah ke netral) perlakuan porang 0,5\% diperoleh kadar air 64,39\%, total padatan terlarut $14,80 \%$, overrun $68,50 \%$, stabilitas emulsi $87,41 \%$, waktu leleh 95,45 menit/100 gram, viskositas 54.5 dPa.s, skor hedonik rasa 3,95 (agak suka mengarah ke suka), hedonik tekstur 4,33 (suka), skoring tekstur 4,53 (agak lembut mengarah ke lembut).

\section{KESIMPULAN}

Berdasarkan hasil penelitian diketahui bahwa perlakuan terbaik adalah es krim buah naga merah yaitu jenis penstabil porang dengan konsentrasi $0,5 \%$. Perlakuan tersebut secara umum mampu menyamai CMC sebagai penstabil es krim. Pada perlakuan porang $0,5 \%$ diperoleh overrun $68,50 \%$, stabilitas emulsi 87,41\%, waktu leleh 97.7 menit/100 gram, viskositas $54.5 \mathrm{dPa}$ s, skor hedonik rasa 3,95 (agak suka mengarah ke suka), hedonik tekstur 4,33 (suka), skoring tekstur 4,53 (agak lembut mengarah ke lembut).

\section{DAFTAR PUSTAKA}

Akesowan A. 2008. Effect of combined stabilizer containingkonjac flour and k-carragenan on ice cream. AUJournal of Thailand, 12(2):81-85

Arbuckle WS. 2000. Ice Cream Third Edition. Avi Publishing Company. Inc West Port, Connecticut

Cahyono B. 2009. Buku Terlengkap Sukses Bertanam Buah Naga. Pustaka Mina, Jakarta.

Estiasih T. 2005. Teknologi Pengolahan Pangan. PT Bumi Aksara. Jakarta

Goff HD. 2000. Controlling Ice Cream Structureby Examining Fat Protein Interactions. J. Dairy Technology. Australia:1-82.

Hakim L. 2013. Penambahan Gum Guar pada Pembuatan Es Krim Instan Ditinjau dari Viskositas, Overrun, dan Kecepatan Meleleh. [Skripsi]. Malang: Fakultas Peternakan, Universitas Brawijaya.
Hartel RW dan Muse MR. 2004. Ice cream structural Elements that affect Melting Rate and Hardness. J of Dairy Science, 87(1): Proquest Agriculture Journals pg.1

Maape E and Donald P. 1979. The Philippines Recommends for Gabi, 1-11. The Philippine Council for Agric. and Res. Reseach College, Laguna.

Malaka R. 2010. Pengantar Teknologi Susu. Masagena Press. Makassar.

Meir H. 1967. Mannan and Galactomannan Advance in Carbohydrate 21,102123. Academic, New York.

Ohtsuki T. 1968. Studies on reserve carbohidrates of flour Amorphophallus sp. with special reference to mannan. Botanical Magazine 81: 119-126.

Pinus L, Sarwono B dan Rahadi F. 1986. Bertanam Umbiumbian, 141-185; 260-281. Penebar Swadaya, Jakarta.

Rahayu WP. 1998. Penuntun Praktikum Penilaian Organoleptik. Jurusan Teknologi Pangan dan Gizi. Fakultas Pertanian, Institut Pertanian Bogor, Bogor.

Sumarwoto. 2005. Iles-iles (Amorphophallus muelleri Blume); description and other characteristics. Biodiversitas. 6(3): 185-190. http://doi.org/bpnz

Susilorini TE dan Sawitri ME. 2006. Produk Olahan Susu. Penebar Swadaya. Jakarta

Susrini. 2003. Pengantar Teknologi Pengolahan Susu. Fakultas Peternakan Universitas Brawijaya. Malang

Tipson RS. 1975. Advences in Carbohydrate Chemistry and Biochemistry 31: 241-309. Academic, New York.

Winarno FG. 1997. Bahan Tambahan untuk Makanan dan Kontaminan. Pustaka Sinar Harapan. Jakarta

Winarno FG. 2004. Kimia Pangandan Gizi.. PT Gramedia Pustaka Utama, Jakarta

Yamaguchi M. 1983. World Vegetables, 148157. AVI, Westport. 